\title{
Forest growth trends in the eastern United States
}

\author{
by Craig Loehle ${ }^{1}$
}

\section{ABSTRACT}

Changes over the past century in factors such as temperature, precipitation, fire regimes, ozone, atmospheric $\mathrm{CO}_{2}$, and nitrogen deposition naturally lead to questions about forest growth over this same time period. Determining changes in forest growth over long intervals is complicated by constantly changing growth conditions due to tree maturation, stand self-thinning, disturbance, fires, and other factors. Because a comprehensive review is lacking, results were evaluated from publications examining forest growth trends in the eastern United States over the past 100 years. Available studies used multiple sources of data, including permanent plots, growth models, and tree-ring analysis to evaluate forest growth trends. Reviewed publications $(n=19)$ reported medium to strong growth enhancement based on a variety of data types over periods exceeding 100 years in some cases. Model-based analyses, which mostly did not include $\mathrm{CO}_{2}$ and nitrogen fertilization effects, had lower estimates of growth enhancement. Results were consistent for different study lengths and data types. No study reported forest-scale growth declines. Factors identified as the cause of enhanced growth varied by study, but included rising $\mathrm{CO}_{2}$ concentrations, $\mathrm{N}$ deposition, increased precipitation, and warming temperatures.

Key words: climate change, environmental factors, forest growth and yield, forest growth trends, inventory data, eastern United States

\section{RÉSUMÉ}

Les changements survenus au cours du dernier siècle dans des facteurs comme la température, les précipitations, le régime des feux, l'ozone, le $\mathrm{CO}_{2}$ atmosphérique, et les dépôts azotés soulèvent naturellement des questions sur la croissance de la forêt au cours de la même période. Il est par ailleurs difficile d'évaluer le changement dans la croissance de la forêt sur de longues périodes en raison des changements continuels des conditions de croissance dus à la maturation des arbres, à l'éclaircie naturelle des peuplements, aux perturbations, aux incendies forestiers et aux autres facteurs. À défaut d'une étude globale sur le sujet, nous avons tenté d'obtenir des résultats à partir des publications scientifiques qui se sont penchées sur les tendances de la croissance forestière aux États-Unis au cours des 100 dernières années. Les études à notre disposition s'appuient sur différentes sources d'informations comme des placettes permanentes, des modèles de croissance et des études d'anneaux de croissance pour évaluer les tendances de la croissance forestière. Les publications que nous avons consultées $(n=19)$ rapportent une augmentation moyenne à forte de la croissance basée sur divers types de données qui, dans certains cas, couvrent des périodes dépassant les 100 ans. Les études réalisées à partir de modèles de prédiction qui, le plus souvent, faisaient abstraction des effets de la fertilisation $\mathrm{au}_{\mathrm{CO}}$ ou à l'azote avaient des estimations plus faibles des gains en croissance. Les résultats allaient dans le même sens, peu importe la durée de l'étude ou le type de données. Aucune étude n'a par ailleurs conclu à un déclin de la croissance à l'échelle de la forêt. Ce sont des facteurs comme la hausse des concentrations de $\mathrm{CO}_{2}$, les dépôts azotés, l'accroissement des précipitations ainsi que le réchauffement des températures qui expliqueraient l'augmentation de la croissance.

Mots-clés : changement climatique, facteurs environnementaux, croissance et rendement des forêts, tendances de la croissance forestière, données d'inventaire, Est des États-Unis

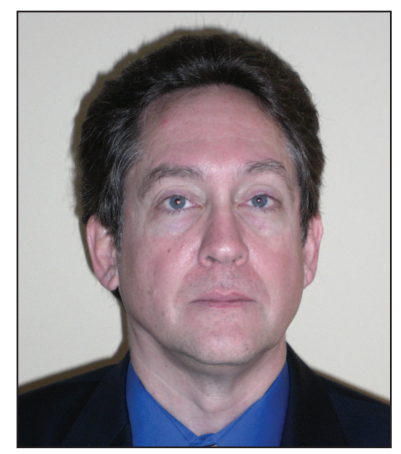

Craig Loehle

\section{Introduction}

Forest productivity is of critical interest to the public, forest landowners, and the forest products sector. There are reported changes over the past century in climate-related and other environmental factors that have the potential to influence forest growth, such as ozone levels, nitrogen deposition, atmospheric $\mathrm{CO}_{2}$ concentrations, temperature, and precipitation (Peñuelas et al. 2013). The magnitude and pattern of reported changes in some of these factors have varied regionally. For example, Bishop et al. (2019) reported rising precipitation across most of the eastern US, with varying subregional trends by season. Kim et al. (2012) detected

\footnotetext{
National Council for Air and Stream Improvement, 1258 Windemere Avenue, Naperville IL 60564 USA e-mail: cloehle@ncasi.org
} 
increasing non-frozen seasons for soils in the Northern Hemisphere during 1979 to 2008. Various authors (e.g., Anderegg et al. 2015; McDowell and Allen 2015; McDowell et al. 2016) have predicted that changing conditions will lead to widespread forest mortality and/or dieback and may already be doing so.

There is some evidence that forest growth may have increased over the last 100 years. Using models and fixed land cover types, O'Sullivan et al. (2019) estimated a 17.4\% net primary productivity (NPP) increase globally from 1901 to 2016, much of it in forests. Global surveys combining various types of data also suggest that forest growth is increasing on average (e.g., Boisvenue and Running 2006, although this study did not include much data specific to the eastern US). A complication with some broad-scale studies (not the O'Sullivan et al. 2019 study) is that global C uptake is influenced not just by tree growth rates per se but by forest regrowth such as following fire and afforestation (Pugh et al. 2019), by changes over time in species composition due to succession, and by disturbance rates. Because of the multiplicity of potential causal pathways and interactions, general discussions of effects of changing conditions on ecosystems (e.g., Peñuelas et al. 2013) have been unable to reach specific conclusions. An empirical approach seems warranted.

The contradiction between predictions that changing conditions should be having adverse effects on forests and evidence to the contrary needs resolution. It clearly affects determination of forest health, near-term future trends for forest resources, and provision of ecosystem services. Therefore, I synthesized information on historical trends in forest growth in a specific region (eastern US) to help resolve this uncertainty. The eastern US acts as a sort of natural experiment because climate is favorable for tree growth and historical climate data are available for comparison. Two companion reviews cover Canada (Loehle and Solarik 2019) and the western United States (Loehle 2020). The metric of interest is measured or simulated historical forest growth rates, not changes in acreage of forest or changes in forest age classes (i.e., not carbon stocks).

The metric of interest here is growth rate of existing stands in terms of site (stand) productivity rather than landscapescale productivity, which can vary based on land use change and stand ages. Ideally, this can be captured as area-based net primary productivity (NPP). Flux tower measurements of $\mathrm{CO}_{2}$ exchange capture whole canopy growth on a plot. All other growth estimates are necessarily based on measurements (or simulations) of individual trees, usually on a plot of defined area. Stand (plot) estimates of growth represent samples from the forest and thus provide an estimate of forest productivity. Stand basal area, when combined with height, is a good predictor of total stand biomass because individual tree biomass can be predicted from allometric equations. Growth models can likewise be used to predict stand biomass and NPP. Ring width will be greater under better growing conditions, but I next discuss cautions in using this metric. All of these metrics are roughly correlated indicators of growing conditions.

A frequently used metric for tree growth is detrended tree ring width. Detrending accounts for the normal decrease in ring width due to stem geometry and tree age. A problem with detrending arises if a gradual change occurs over time due, for example, to slowly rising carbon dioxide, the effect of which will be correlated with tree age. The age detrending methods used (of which there are many) to adjust growth histories to account for tree aging and stem geometry can in many cases dampen the long-term growth signal (i.e., any historical trend) by confounding it with tree age (Esper et al. 2004, 2005a, 2005b, 2007; von Storch et al. 2004), though Franke et al. (2013) argued that such detrended series exaggerate low-frequency signals. When stand density can change over time (due to ingrowth or mortality), standardization is further compromised (Cherubini et al. 1998; Carrer 2011; Nehrbass-Ahles et al. 2014). Given this controversy and the complex interactions among stand structure, individual tree growth, and total productivity (Forrester 2019), it is prudent to avoid studies that used detrended ring data. An approach that overcomes these issues is to use age-matching to compare trees at the same age but different establishment dates. If old trees are available, an age-ring width model can be developed. Then, deviations in growth from this model can be examined over the period of interest for younger trees. This method removes concerns about standardization (i.e., no detrending is done) and allows one to evaluate trends, assuming that stand density was similar at the two times. One caution is that there may exist growth rate trade-offs with mortality, such that very old trees may be slower growing (Loehle 1988; Büntgen et al. 2019), creating a bias toward detecting recent increased growth with age-matching.

Inventory plots can be used to estimate growth of either wood volume or NPP (aboveground or total) using various methods (Talbot et al. 2014; Searle and Chen 2017; Kohyama et al. 2019). To estimate growth rate changes, at least three inventory-based estimates are needed (e.g., 1995, 2000, 2005), where each pair (e.g., 1995-2000) gives an estimate of growth rate to compute a change of rate. Various complications exist, but most are not critical in eastern forests. High turnover during long sample intervals, for example, is a larger problem in tropical forests where trees can grow into a plot, die, and decay before being sampled. In this study, however, I am concerned with net stand level biomass accumulation, ignoring such fine scale mortality turnover. Size thresholds (e.g., 5-cm dbh) for sample inclusion may bias NPP down slightly, but this problem is only significant where growth is very rapid (e.g., tropical forest). Other inaccuracies in estimating growth, per above, are minor or are minimized if the same methods are used over time, as I am interested in growth rate changes rather than absolute rates.

Comparison of stand growth rates over time must account for stand age. The net effect of stand dynamics for even-aged stands is an area-based pattern of accelerating growth, a peak shortly after crown closure, and a long decline period (Girardin et al. 2011; Boisvenue et al. 2016; Hogg et al. 2017). This dynamic can be captured using Hoerl's function (Eq. 1):

$$
\Delta A G B=\beta_{0}(\text { age })^{\beta_{1}} e^{\beta_{2}(a g e)}
$$

where $\beta_{0}, \beta_{1}, \beta_{2}$ are fitted parameters that change curve height and shape to reflect species and growing conditions, and $\triangle A G B$ is above ground live biomass increment per year per ha, usually live only.

In Fig. 1, a typical curve as estimated (their Fig. 6) by Boisvenue et al. (2016) is shown. Other functional forms 


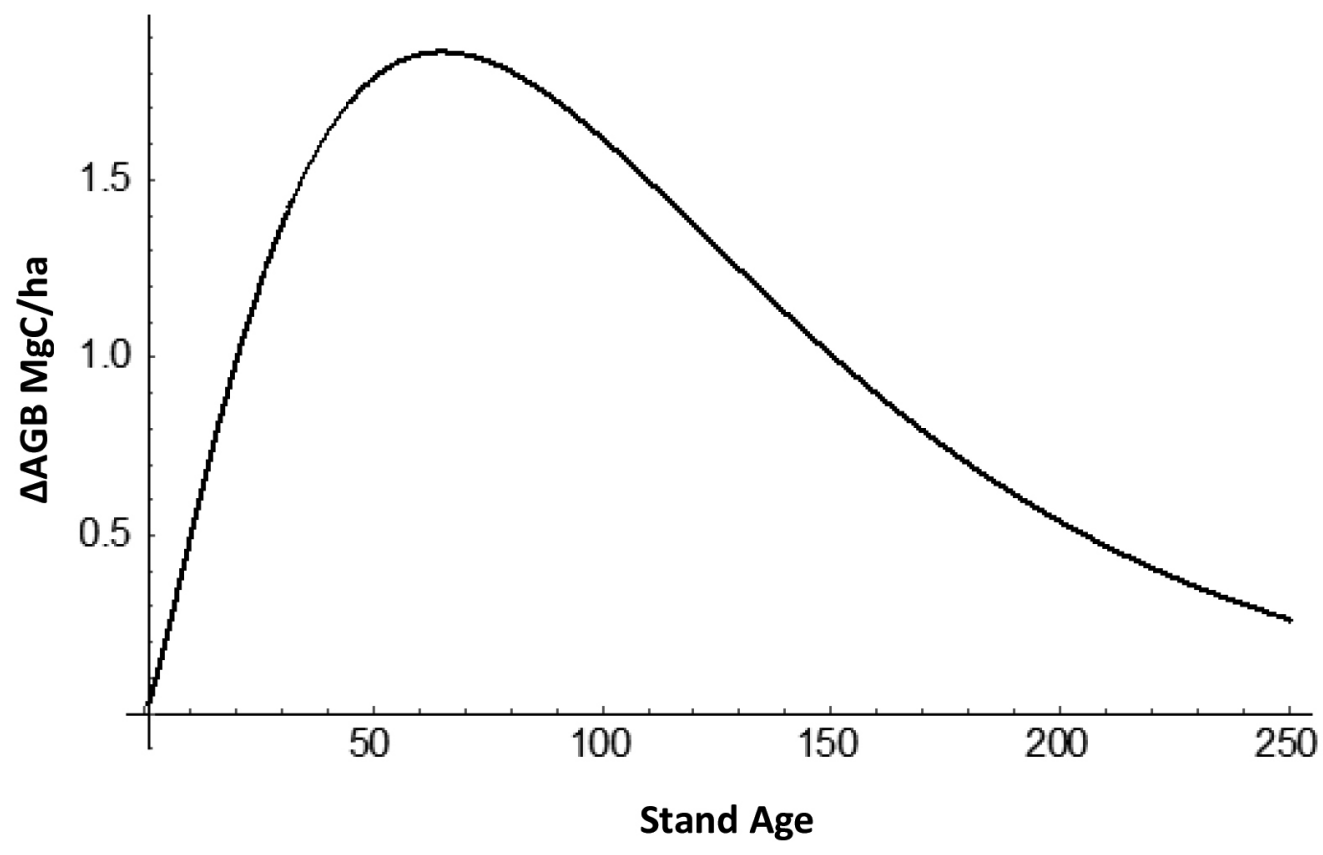

Fig. 1 Typical growth curve (Hoerl's function) for trees in even-aged stands on a unit area basis (based on Boisvenue et al. 2016); other functional forms (e.g., McMahon et al. 2010) give similar results.

(e.g., McMahon et al. 2010) can also be used. The decline phase is partially due to increased mortality resulting from crowding and tree aging (Hogg et al. 2017) and reduced hydraulic efficiency with age or height (Baret et al. 2018). Growth response of older stands could thus be misleading if a reduction in growth resulted from maturation rather than changes in environmental conditions. In northern Minnesota, growth variations due to climate were $92-95 \%$ smaller than those due to tree size and age (Foster et al. 2014).

Height growth rate of dominant trees, commonly used to construct site index metrics, is less affected by competition (Bontemps et al. 2011) and could provide a useful approach for estimating growth trends. In plantations, where spacing and age are uniform, height at a given age for older and younger stands could be compared either from inventory data or from tree dissections, although similar sites should be compared (Lieffers et al. 2018). For plantations on similar sites, yield tables from past harvests or tree sizes (height or biomass) at given ages can be validly compared. Planting density must be the same, as should treatments (e.g., thinning, fertilization), for such comparisons to be valid. Genetic improvement of planting stock over time could also confound results.

Finally, short- versus long-term data may show different trends. A region that is experiencing increased growth over the past 100 years due to changing climate factors (e.g., precipitation, temperature) and/or rising $\mathrm{CO}_{2}$ might nevertheless show a recent short-term decline in growth due to drought, pests, or stand aging. A recent period could also have abnormally good growing conditions. It is therefore important to consider multiple sites and the longest time periods possible.

Remote sensing data are widely used for estimating leaf area and productivity. However, based on strong contradictions found between temporal forest productivity trends using remote sensing vs. other methods (e.g., Marchand et al. 2018) and signal saturation at high leaf area, such studies are not used in this review.

Alterations in forest growth caused by human land use are not considered here. Area in forest may change due to farm abandonment, for example, which would affect carbon stocks. However, the focus here is on productivity of forest stands, not landscape carbon pools. Thus, studies that simulate combined historical effects of the environment and land use change (e.g., Tian et al. 2010, 2012) are not informative about stand-level NPP unless land use is considered separately. The long-term effects of agricultural land abandonment and succession on species composition and consequent productivity (Nowacki and Abrams 2015) is mostly at longer time-scales than the studies reviewed here, but were considered in interpreting reviewed studies if relevant. Also not considered are changes in forest carbon stocks caused by disturbances (e.g., Kautz et al. 2018). These factors would need to be considered for assessing carbon pools but not for growth rate per se. Long-term inventory data do encompass small-scale disturbances (e.g., insect attack) but not standreplacing disturbances.

Because of changes in precipitation, nitrogen deposition, temperature, $\mathrm{CO}_{2}$, and other factors, attribution of forest growth changes can be complex and often requires evalua- 
tion of several types of evidence. In the studies described next, more than one environmental factor often could have caused observed changes in forest growth. In such cases, the authors of these studies sometimes made inferences from historical data to help clarify causation.

\section{Methods}

I searched the scientific literature for references to long-term growth trends of forests in the eastern US. I selected studies if they covered any part of the eastern US, defined as forested areas east of the Great Plains (i.e., starting in the states just west of the Mississippi River). As an initial entry to the literature, I manually searched (i.e., contents read) the complete contents of Forest Science (2015-2018), Canadian Journal of Forest Research (2012-2018), Forest Ecology and Management (2012-2018), Global and Planetary Change (2014-2017), and Global Change Biology (2012-2018). This search included over 6000 articles. I also searched the literature with Google Scholar using "tree-ring chronologies", "forest history", "NPP", "growth reconstruction", "forest greening", "forest browning", "forest growth decline", "forest growth acceleration", "forest growth trends", "forest carbon dynamics", and "carbon sequestration" as keywords. I also searched the International Tree-Ring Data Bank (ITRDB) for relevant studies. I then searched cited literature in each publication. To be included in the analysis, studies needed to use age-matching, stand-scale metrics, or models of stands to avoid complications documented in the introduction. Studies needed to consider a single species or fixed forest type such as northern hardwoods. For example, a study in which aspen forest transitioned to spruce would not give consistent results. Growth rates estimated at least at two times were needed for a study to be included as measures of biomass at two times only yield a single rate, not two. While studies differed in their metrics (ring width vs. NPP, for example), species studied, and geographic coverage, they can all be considered independent rate of change estimates. For some of the studies, I used conservative values where there were uncertain age, scale, or metric values. I was unable to use many additional studies because their focus was on growth responses to seasonal weather factors or estimation of historical climate from tree rings, for example, and growth trends could not be extracted from their data. Many studies I retrieved with key words did not document changes in growth rates per se, but only metrics such as biomass at two different times or growth rate at a single time and could thus not be used. Some entries in the ITRDB did not contain meta-data. Other studies did not separate forest growth rates from regional or national ecosystem totals that included non-forest lands (e.g., Chen et al. 2012).

\section{Results}

I found nineteen publications that quantified forest growth trends in the eastern US over time (Table 1). Four additional studies provided qualitative results. Reviewed studies estimated forest growth rates over periods ranging from 10 years to the century scale. I used modeling studies and those based on various types of long-term data (inventories, tree-ring reconstructions, flux towers, plot data) in this review. Most studies used in what follows either sampled multiple stands or simulated many plots to obtain their growth estimates and can thus be considered forest-level estimates of growth. The basic types of studies found were modeling $(n=7)$, agematching $(n=4)$ and plot-based data $(n=7)$, where Twine and Kucharik (2009) calculated trends for broadleaf and conifer separately. See the Supplemental Information for details of cited studies.

I found seven modeling studies (Joos et al. 2002; Del Grosso et al. 2008; Pan et al. 2009; Twine and Kucharik 2009; Motew and Kucharik 2013; Rollinson et al. 2017; O'Sullivan et al. 2019). An advantage of modeling studies is that the forest age and composition can be held constant, eliminating tree age and successional effects on productivity. Joos et al. (2002), Del Grosso et al. (2008), Rollinson et al. (2017), O'Sullivan et al. (2019), and found positive growth trends across the entire region. Twine and Kucharik (2009) found positive trends for broadleaf forest over the entire region but no trend for coniferous species, though they held $\mathrm{CO}_{2}$ constant in their analysis. Rollinson et al. (2017) found positive trends in New England and the Upper Midwest. Pan et al. (2009) found increased growth in the Mid-Atlantic States (Virginia north to New York). The studies with fixed $\mathrm{CO}_{2}$ (Del Grosso et al. 2008; Twine and Kucharik 2009; Motew and Kucharik 2013) may have underestimated growth enhancement based on Loehle (2018). The modeling studies variously ascribed increased growth to rising $\mathrm{CO}_{2}, \mathrm{~N}$ deposition, warming, increased precipitation, or a combination of these. Only Pan et al. (2009) modeled ozone effects and found an $8 \%$ growth reduction over the period $1895-2000$, but with other factors more than compensating for this detriment.

Four studies used age-matching. With this method, individual tree growth (ring width, basal area increment, or height) is compared between young trees and older trees when they were that same age. This method controls for both age and competition effects. Two studies evaluated longleaf pine (Pinus palustris Mill.), in southern Georgia using ring widths (West et al. 1993) and in southern Alabama using height metrics (Boyer 2001) and both found substantial growth increases in recent decades. Voelker et al. (2006) found a doubling of oak (two Quercus spp.) growth over the period 1840 to 1980 . Cole et al. (2010) found a 60\% growth enhancement of quaking aspen (Populus tremuloides Michx.) in Wisconsin over roughly 1950 to 2000 . Authors attributed growth enhancements to $\mathrm{N}$ deposition and $\mathrm{CO}_{2}$ (West et al. 1993), $\mathrm{CO}_{2}$ (Voelker et al. 2006), and $\mathrm{CO}_{2}$ plus precipitation (Cole et al. 2010).

The remaining studies were based on long-term plot data. Dragoni et al. (2011) and Keenan et al. (2012) used $\mathrm{CO}_{2}$ flux data in south-central Indiana and the Harvard Forest, respectively, with both finding large recent increases in $\mathrm{C}$ uptake at decadal scales. Plot-based studies across the Northeast (Hornbeck et al. 1988; Thomas et al. 2009; McMahon et al. 2010; Dye et al. 2016; Pontius et al. 2016) found increased growth at the stand level and for many species. These growth enhancements were variously attributed to $\mathrm{N}$ deposition, warming, longer growing seasons, and rising $\mathrm{CO}_{2}$.

Red spruce (Picea rubens Sarg.) decline has historically been of concern. Both Engel et al. (2016) and Mathias and Thomas (2018) found red spruce growth to have fluctuated due to weather and pollution episodes, with a recent increase in growth. Hornbeck et al. (1988), Battles et al. (2003), and Gavin et al. (2008), found historic (1960s to 1980s) decline and mortality of red spruce in New England followed by recovery. 
Table 1. Summary of Growth Trend Results ${ }^{a}$

\begin{tabular}{|c|c|c|c|c|}
\hline Reference & Years & Region & Methods & Trend \\
\hline Boyer 2001 & $\begin{array}{l}1964-2000 \mathrm{AL} \\
\text { ( 44 yr difference) }\end{array}$ & Longleaf pine site index & $+28 \%$ age 50 site index & $\begin{array}{l}(+6.4 \% / \text { decade }) \\
(+30-35 \% \text { wood volume })\end{array}$ \\
\hline Cole et al. 2010 & 1935-2003 & WI & Aspen ring width & $\begin{array}{l}+60 \% \text { for young trees over } 50 \\
\text { yr period }(+12 \% / \text { decade })\end{array}$ \\
\hline Del Grosso et al. 2008 & $1901-2000$ & US \& Canada & $\begin{array}{l}\text { Simulated NPP with } \\
\text { fixed } \mathrm{CO}_{2}\end{array}$ & $\begin{array}{l}+3 \% \text { to } 7.7 \% \text { tNPP increase } \\
(+0.3-0.77 \% / \text { decade })\end{array}$ \\
\hline Dragoni et al. 2011 & $1998-2008$ & South-Central Indiana & Flux tower measurements & $\begin{array}{l}38 \% \text { NEP increase } \\
\text { (38\%/decade) }\end{array}$ \\
\hline Dye et al. 2016 & $1970-2010$ & Three sites in ME, MA, WV & $\begin{array}{l}\text { Permanent plots \& } \\
\text { tree-ring data }\end{array}$ & $\begin{array}{l}\text { No NPP trend but data highly } \\
\text { variable }\end{array}$ \\
\hline Engel et al. 2016 & $1951-2010$ & Vermont \& New Hampshire & $\begin{array}{l}\text { BAI of dominant, } \\
\text { co-dominant red spruce }\end{array}$ & $\begin{array}{l}\text { Zero trend 1951-1999; } \\
33 \% \text { increase } 2000-2010 \\
\text { (33\%/decade) }\end{array}$ \\
\hline Keenan et al. 2012 & 1992-2009 & Harvard Forest & Eddy-covariance data & $\begin{array}{l}\text { Doubling of NEE } \\
\text { (59\%/decade) }\end{array}$ \\
\hline $\begin{array}{l}\text { Mathias and } \\
\text { Thomas, } 2018\end{array}$ & 1960-2014 & Central Appalachians & $\begin{array}{l}\text { Basal area increment of } \\
\text { dominant red spruce }\end{array}$ & Net zero growth rate \\
\hline McMahon et al. 2010 & $1987-2005$ & Maryland & $\begin{array}{l}\text { Compared resurvey periodic } \\
\text { increment on stands of } \\
\text { multiple ages to expected } \\
\text { trend from biomass vs age } \\
\text { curve }\end{array}$ & $\begin{array}{l}\text { All ages were growing faster } \\
\text { than predicted, up to twice as } \\
\text { fast, } 50 \% \text { increase conserva- } \\
\text { tively used in analyses (no time } \\
\text { period) }\end{array}$ \\
\hline $\begin{array}{l}\text { Motew and } \\
\text { Kucharik } 2013\end{array}$ & 1948-2007 & MN, WI, MI & Simulated NPP & +8\% NPP (1.4\%/decade) \\
\hline O’Sullivan et al. 2019 & $1901-2016$ & E US & $\begin{array}{l}\text { Used simulated climate, } \\
\mathrm{N} \text { deposition, } \mathrm{CO}_{2} \text { histories } \\
\text { to model NPP }\end{array}$ & $\begin{array}{l}+50-100 \mathrm{~g} \mathrm{C} / \mathrm{m}^{2} / \mathrm{yr} \text { increase } \\
\text { (from map) }(+4.3-8.6 \mathrm{~g} \\
\mathrm{C} / \mathrm{m}^{2} / \text { decade increase) }\end{array}$ \\
\hline Pan et al. 2009 & $1895-2000$ & US Mid-Atlantic & $\begin{array}{l}\text { Used simulated climate, } \\
\mathrm{N} \text { deposition, } \mathrm{CO}_{2} \text { histories } \\
\text { to model NPP }\end{array}$ & $\begin{array}{l}\mathrm{NPP} \text { increased } 29 \% \\
(2.8 \% / \text { decade) due to net } \mathrm{N} \text {, } \\
\mathrm{CO}_{2}, \mathrm{O}_{3} \text { effects, }+4 \% \text { due to } \\
\text { simulated climate change } \\
\text { alone }\end{array}$ \\
\hline Pontius et al. 2016 & $1931-2001$ & New Hampshire & Long-term plot data & $\begin{array}{l}90 \% \text { higher } 10 \text {-year NPP } \\
\text { increments for most recent } \\
\text { survey }\end{array}$ \\
\hline Rollinson et al. 2017 & $1880-2010$ & Upper Midwest and NE & $\begin{array}{l}\text { Models calibrated to tree- } \\
\text { ring data }\end{array}$ & $\begin{array}{l}+37.5 \% \text { NPP increase, mainly } \\
\text { due to } \mathrm{CO}_{2}, 32 \% \text { after } 1940 \\
(+4.6 \% / \text { decade })\end{array}$ \\
\hline Thomas et al. 2009 & $\begin{array}{l}\text { Pre-industrial } \\
\text { vs recent }\end{array}$ & Midwest \& NE US & $\begin{array}{l}\text { Based on FIA data \& N depo- } \\
\text { sition, estimated N effect on } \\
\text { growth }\end{array}$ & $\begin{array}{l}+40 \% \text { biomass growth } \\
\text { enhancement but } \mathrm{CO}_{2} \text { effect } \\
\text { could not be separated }\end{array}$ \\
\hline $\begin{array}{l}\text { Twine and } \\
\text { Kucharik } 2009\end{array}$ & 1950-2002 & Eastern US & $\begin{array}{l}\text { Modeled forest NPP growth } \\
\text { by vegetation type }\left(\mathrm{CO}_{2}\right. \\
\text { constant) }\end{array}$ & $\begin{array}{l}+5 \% \text { deciduous forest } \\
(+0.96 \% / \text { decade }) 0 \% \text { conifer } \\
\text { forest }\end{array}$ \\
\hline Voelker et al. 2006 & $1840-1980$ & $\mathrm{MO}$ & Tree rings & $+100 \%(+7.1 \% /$ decade $)$ \\
\hline West et al. 1993 & 1940-1987 & South GA & Tree rings & $\begin{array}{l}+44.5 \% \text { ring index } \\
(+9.5 \% / \text { decade })\end{array}$ \\
\hline
\end{tabular}

aSome model study results interpreted from color-coded maps. In case of ambiguity, lower bounds on estimates were chosen. Twine and Kucharik (2009) provided rates separately for conifer and broadleaf types and both were used. Trends are over the reported time period. See Supplemental Information for details of analysis. 
Another species of concern is sugar maple (Acer saccharum Marsh.). Aside from a decline at one site in Vermont (Gavin et al. 2008) and enhanced growth across New England from the 1960s to 1980s (Hornbeck et al. (1988), the plot-level and modeling studies did not detect a significant maple growth decline signal.

We can summarize these results by several categories: models $(n=7)$, age match $(n=4)$, plots $(n=7)$, and all $(n=$ 18). Data were converted to percent change for comparisons (Fig. 2). O'Sullivan et al. (2019) could not be converted from g C $/ \mathrm{m}^{2} / \mathrm{yr}$ increase to a percent and was not included. Keenan et al. (2012) produced a 33\% increase over just 10 years, which is probably an outlier due to either methods or local weather fluctuations and was also left out. Age matching had the highest mean increase per century (85\%) compared to plots $(69 \%)$, models (16\%), and all sources (52\%). These values are conservative because positive model and plotbased results were not included (as noted above). Models showed a much reduced positive response compared to data studies, perhaps due to factors such as $\mathrm{CO}_{2}$ and $\mathrm{N}$ deposition being inadequately represented. The lowest percent change over all the data is zero. No study found a growth decline.

\section{Discussion}

Quantifiable growth enhancements, some large, over up to 100-year time-frames are evident in the eastern half of the US (Table 1). The mean growth enhancements over all studies fall mostly in the range of $20 \%$ to $90 \%$ per century, with growth enhancements being variously ascribed by investiga- tors to $\mathrm{CO}_{2}, \mathrm{~N}$ deposition, precipitation, warming, or some combination of these. A few studies did not detect a trend but no study showed declining growth. No study quantified or implicated ozone as a damaging agent, except Pan et al. (2009), who found an $8 \%$ growth reduction that was more than compensated by growth enhancements from other causes. While periodic mortality or declines of, for example, sugar maple, would seem to be negative indicators, overall negative trends at the forest level were not detectable with any of the data available, and even sugar maple showed increasing trends in some studies. Red spruce decline trends observed prior to the 1980s would seem to have been reversed. The trends detected are despite a detectable shift toward more shade-tolerant, slower-growing species due to successional changes and other factors over the centennial scale (Knott et al. 2019). Low rates of increase found in several modeling studies were probably underestimates because leaving $\mathrm{CO}_{2}$ out of models reduces simulated growth trends (Loehle 2018). Growth trends seem consistent across the region and for the forest types studied, but formal tests were precluded by small sample sizes.

The question of scale needs to be considered. The modeling studies typically simulated many plots across their study area and are thus spatially extensive. Field studies sampled multiple multi-species plots, while a few focused on a single species (e.g., Cole et al. 2010). Only West et al. (1993) could be said to suffer from a small sample size but their results were corroborated by Boyer (2001). Given that studies that focused on different species and sub-regions all generally

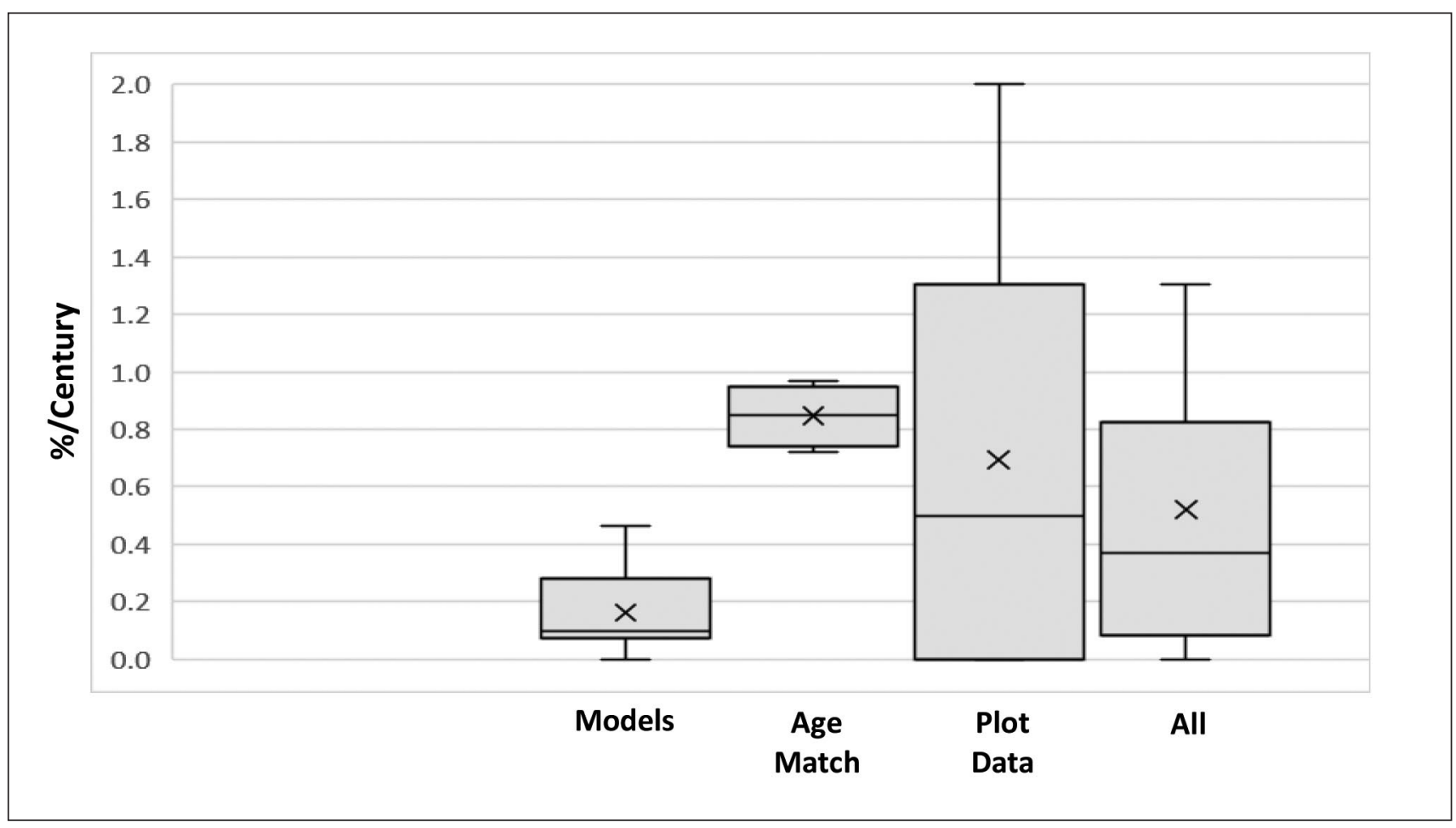

Fig. 2 Box and whisker plot for percent growth change per century for 18 studies. X represents the mean. Keenan et al. (2012) was so large that it was left out and probably represents very short-term weather responses. O'Sullivan et al. (2019) could not be converted to percent and is not plotted. Twine and Kucharik (2009) provided trends for broadleaf and conifers separately. 
agreed on trends, this supports the conclusion that regional growth has been generally increasing. Given the evidence for rising effective moisture across the region (Greve et al. 2014), $\mathrm{N}$ deposition, and rising $\mathrm{CO}_{2}$, this response makes sense. Because the growth enhancing factors ( $\mathrm{N}$ deposition, rising precipitation, and rising $\mathrm{CO}_{2}$ plus perhaps warming) have all been increasing in concert in this region, it is not possible to separate their effects in general, though attempts were made to do so in a few of the studies cited here. Growth rate data were in general only available at two or a few periods so that correlations of growth with these factors is generally not possible.

Small-scale or non-catastrophic disturbances and mortality including insect/pathogen attack are present on most study plots and are thus factored into rate changes. If plots burned up or blew down, they obviously could not be remeasured. While this might affect extrapolation for regional carbon balance calculations, my concern here is with growth rates of existing stands. If disturbance rates were increasing, as with western fires in recent decades, this would bias my results upward, but there is little evidence for this in the eastern US (e.g., Cohen et al. 2016).

Several introduced insect pests and pathogens have been affecting multiple species. For example, exotic earthworm invasion of the Upper Midwest is quite recent and is affecting growth of sugar maple (Bal et al. 2018). However, some species sampled (e.g., longleaf pine) are not experiencing effects from introduced pathogens and cited modeling studies did not include their effects. Given that episodic weather events (storms, drought) and insect (and other) damage is always present, the extent to which new damage agents might be causing growth reductions is an open question. Results of this survey thus capture the baseline forest growth responses including normal climatic fluctuations and damage agents but not recent invasive pest effects, though some studies did avoid stands with major disturbances. Overall, the significant growth enhancements found here are consistent with other studies (e.g., Joos et al. 2002; Boisvenue and Running 2006; Pugh et al. 2019) which could not be directly compared to Table 1 entries due to scale or location differences.

The weight of evidence from reviewed studies indicates that, in the study area, growth relationships have been changing over time. An assumption underlying yield tables and site index curves in forestry is that short-term weather fluctuations will average out over the life of a stand, making growth projections mostly reliable. If conditions change radically over decades, however, such relationships could be altered. Numerous studies cited here found major increases in productivity over just the past few decades. Thus, indicators of growth such as yield tables and site index curves, even from the 1980s, might significantly underestimate growth. Impacts on stand economics of changing growth need not be in the distant future (per Johnston and Williamson 2005) to warrant consideration. A general ongoing effect is rising $\mathrm{CO}_{2}$ which accelerates early tree growth (Loehle 1995; LaDeau and Clark 2001) thus potentially distorting yield tables, site index curves, and stand growth-density responses (Kubiske et al. 2019), while favoring some species more than others. Also, as $\mathrm{CO}_{2}$ rises, trees become more fecund at an earlier age (LaDeau and Clark 2001), with implications for seed orchards and natural regeneration. Finally, ongoing growth changes may require reassessment of seed zones for tree planting (McKenney et al. 2009).

Trends observed to date in this region obviously cannot be simply extrapolated into the future. While it is fairly predictable that $\mathrm{CO}_{2}$ will continue to rise, other climatic changes are less certain. A recent synthesis of climate projections and consequent forest growth responses (Loehle 2018) indicates that, in this region, growth trends are likely to be generally positive in coming decades, with some local disruptions or southern ecotone range retractions possible.

\section{Acknowledgements}

Thanks to D.A. Miller and T.B. Wigley for helpful suggestions. This work was funded by the National Council for Air and Stream Improvement, Inc. (NCASI). The author asserts no conflicts of interest.

\section{References}

Anderegg, W.R.L., A. Flint, C.-Y. Huang, L. Flint, J.A. Berry, F.W. Davis, J.S. Sperry and C.B. Field. 2015. Tree mortality predicted from drought-induced vascular damage. Nat. Geosci. 8(5): 367-371. doi:10.1038/ngeo2400.

Bal, T.L., A.J. Storer and M.F. Jurgensen. 2018. Evidence of damage from exotic invasive earthworm activity was highly correlated to sugar maple dieback in the Upper Great Lakes region. Biol. Invasions 20(1): 151-164. doi:10.1007/s10530-017-1523-0.

Baret, M., S. Pepin and D. Pothier. 2018. Hydraulic limitations in dominant trees as a contributing mechanism to the age-related growth decline of boreal forest stands. Forest Ecol. Manag. 427: 135-142. doi:10.1016/j.foreco.2018.05.043.

Battles, J.J., T.J. Fahey, T.G. Siccama and A.H. Johnson. 2003. Community and population dynamics of spruce-fir forests on Whiteface Mountain, New York: Recent trends, 1985-2000. Can. J. For. Res. 33(1): 54-63. doi:10.1139/x02-150.

Bishop, D.A., A.P. Williams, R. Seager, A.M. Fiore, B.I. Cook, J.S. Mankin, D. Singh, J.E. Smerdon and M.P. Rao. 2019. Investigating the causes of increased twentieth-century fall precipitation over the southeastern United States. J. Clim. 32(2): 575-590. doi:10.1175/jcli-d-18-0244.1.

Boisvenue, C. and S.W. Running. 2006. Impacts of climate change on natural forest productivity - evidence since the middle of the 20th century. Glob. Change Biol. 12(5): 862-882. doi:10.1111/j.1365-2486.2006.01134.x.

Boisvenue, C., B.P. Smiley, J.C. White, W.A. Kurz and M.A. Wulder. 2016. Integration of Landsat time series and field plots for forest productivity estimates in decision support models. Forest Ecol. Manag. 376: 284-297. doi:10.1016/j.foreco.2016.06.022.

Bontemps, J.-D., J.-C. Hervé, J.-M. Leban and J.-F. Dhôte. 2011. Nitrogen footprint in a long-term observation of forest growth over the twentieth century. Trees 25(2): 237-251. doi:10.1007/s00468010-0501-2.

Boyer, W.D. 2001. A generational change in site index for naturally established longleaf pine on a south Alabama coastal plain site. South. J. Appl. For. 25: 88-92. doi:10.1093/sjaf/25.2.88.

Büntgen, U., P.J. Krusic, A. Piermattei, D.A. Coomes, J. Esper, V.S. Myglan, A.V. Kirdyanov, J.J. Camarero, A. Crivellaro and C. Körner. 2019. Limited capacity of tree growth to mitigate the global greenhouse effect under predicted warming. Nat. Commun. 10(1): 2171. doi:10.1038/s41467-019-10174-4.

Carrer, M. 2011. Individualistic and time-varying tree-ring growth to climate sensitivity. PLoS ONE 6(7): e22813. doi:10.1371/ journal.pone.0022813. 
Caspersen, J.P., S.W. Pacala, J.C. Jenkins, G.C. Hurtt, P.R. Moorcroft and R.A. Birdsey. 2000. Contributions of land-use history to carbon accumulation in U.S. forests. Sci. 290(5494): 1148-1151. doi:10.1126/science.290.5494.1148.

Chen, G., H. Tian, C. Zhang, M. Liu, W. Ren, W. Zhu, A. H. Chappelka, S.A. Prior and G.B. Lockaby. 2012. Drought in the southern United States over the $20^{\text {th }}$ century: Variability and its impacts on terrestrial ecosystem productivity and carbon storage. Clim. Change 114(2): 379-397. doi:10.1007/s10584-012-0410-z.

Cherubini, P., M. Dobbertin and J.L. Innes. 1998. Potential sampling bias in long-term forest growth trends reconstructed from tree rings: A case study from the Italian Alps. Forest Ecol. Manag. 109(13): 103-118. doi:10.1016/S0378-1127(98)00242-4.

Cohen, W.B., Z. Yang, S.V. Stehman, T.A. Schroeder, D.M. Bell, J.G. Masek, C. Huang and G.W. Meigs. 2016. Forest disturbance across the conterminous United States from 1985-2012: The emerging dominance of forest decline. Forest Ecol. Manag. 360: 242-252. doi:10.1016/j.foreco.2015.10.042.

Cole, C.T., J.E. Anderson, R.L. Lindroth and D.M. Waller. 2010. Rising concentrations of atmospheric $\mathrm{CO}_{2}$ have increased growth in natural stands of quaking aspen (Populus tremuloides). Glob. Change Biol. 16(8): 2186-2197. doi:10.1111/j.1365-2486.2009. 02103.x.

Del Grosso, S., W. Parton, T. Stohlgren, D. Zheng, D. Bachelet, S. Prince, K. Hibbard and R. Olson. 2008. Global potential net primary production predicted from vegetation class, precipitation, and temperature. Ecol. 89(8): 2117-2126. doi:10.1890/07-0850.1.

Dragoni, D., H.P. Schmid, C.A. Wayson, H. Potter, C.S.B. Grimmond and J.C. Randolph. 2011. Evidence of increased net ecosystem productivity associated with a longer vegetated season in a deciduous forest in south-central Indiana, USA. Glob. Change Biol. 17(2): 886-897. doi:10.1111/j.1365-2486.2010.02281.x.

Dye, A., A.B. Plotkin, D. Bishop, N. Pederson, B. Poulter and A. Hessl. 2016. Comparing tree-ring and permanent plot estimates of aboveground net primary production in three eastern U.S. forests. Ecosphere 7(9): e01454. doi:10.1002/ecs2.1454.

Engel, B.J., P.G. Schaberg, G.J. Hawley, S.A. Rayback, J. Pontius, A.M. Kosiba and E.K. Miller. 2016. Assessing relationships between red spruce radial growth and pollution critical load exceedance values. Forest Ecol. Manag. 359: 83-91. doi:10.1016/ j.foreco.2015.09.029.

Esper, J., D.C. Frank and R.J.S. Wilson. 2004. Climate reconstructions-low frequency ambition and high frequency ratification. EOS Trans. Amer. Geophys. Union 85(12): 113-120. doi:10.1029/ 2004EO120002.

Esper, J., D.C. Frank and J. Luterbacher. 2007. On selected issues and challenges in dendroclimatology. In: F. Kienast, O. Wildi, S. Ghosh (Eds.). A Changing World: Challenges for Landscape Research. pp. 113-132. Springer, Netherlands.

Esper, J., D.C. Frank, R.J.S. Wilson and K.R. Briffa. 2005a. Effect of scaling and regression on reconstructed temperature amplitude for the past millennium. Geophys. Res. Lett. 32(7): L07711. doi:10.1029/2004GL021236

Esper, J., R.J.S. Wilson, D.C. Frank, A. Moberg, H. Wanner and J. Luterbacher. 2005b. Climate: Past ranges and future changes. Quat. Sci. Rev. 24(20-21): 2164-2166. doi:10.1016/j.quascirev.2005.07.001 Forrester, D.I. 2019. Linking forest growth with stand structure: tree size inequality, tree growth or resource partitioning and the asymmetry of competition. Forest Ecol. Manag. 447: 139-157. doi:10.1016/j.foreco.2019.05.053.

Foster, J.R., A.W. D’Amato and J.B. Bradford. 2014. Looking for age-related growth decline in natural forests: Unexpected biomass patterns from tree rings and simulated mortality. Oecol. 175(1): 363-374.

Franke, J., D. Frank, C.C. Raible, J. Esper and S. Brönnimann. 2013. Spectral biases in tree-ring climate proxies. Nat. Clim. Change 3(4): 360-364. doi:10.1038/nclimate1816.
Gavin, D.G., B. Beckage and R. Osborne. 2008. Forest dynamics and the growth decline of red spruce and sugar maple on Bolton Mountain, Vermont: A comparison of modeling methods. Can. J. For. Res. 38(10): 2635-2649. doi:10.1139/x08-106.

Girardin, M.P., P.Y. Bernier and S. Gauthier. 2011. Increasing potential NEP of eastern boreal North American forests constrained by decreasing wildfire activity. Ecosphere 2(3): 1-23. doi:10.1890/ ES10-00159.1.

Greve, P., B. Orlowsky, B. Mueller, J. Sheffield, M. Reichstein and S.I. Seneviratne. 2014. Global assessment of trends in wetting and drying over land. Nat. Geosci. 7(10): 716-721. doi:10.1038/ngeo2247. Hogg, E.H., M. Michaelian, T.I. Hook and M.E. Undershultz. 2017. Recent climatic drying leads to age-independent growth reductions of white spruce stands in western Canada. Glob. Change Biol. 23(12): 5297-5308. doi:10.1111/gcb.13795.

Hornbeck, J.W., R.B. Smith and C.A. Federer. 1988. Growth trends in 10 species of trees in New England, 1950-1980. Can. J. For. Res. 18(10): 1337-1340. doi:10.1139/x88-206.

Johnston, M. and T. Williamson. 2005. Climate change implications for stand yields and soil expectation values: A northern Saskatchewan case study. For. Chron. 81(5): 683-690. doi:10.5558/ tfc81683-5.

Joos, F., I.C. Prentice and J.I. House. 2002. Growth enhancement due to global atmospheric change as predicted by terrestrial ecosystem models: consistent with US forest inventory data. Glob. Change Biol. 8(4): 299-303. doi:10.1046/j.1354-1013.2002.00505.x.

Kautz, M., P. Anthoni, A.J.H. Meddens, T.A.M. Pugh and A. Arneth. 2018. Simulating the recent impacts of multiple biotic disturbances on forest carbon cycling across the United States. Glob. Change Biol. 24(5): 2079-2092. doi:10.1111/gcb.13974.

Keenan, T.F., E. Davidson, A.M. Moffat, W. Munger and A.D. Richardson. 2012. Using model-data fusion to interpret past trends, and quantify uncertainties in future projections of terrestrial ecosystem carbon cycling. Glob. Change Biol. 18(8): 2555-2569. doi:10.1111/j.1365-2486.2012.02684.x.

Kim, Y., J.S. Kimball, K. Zhang and K.C. McDonald. 2012. Satellite detection of increasing Northern Hemisphere non-frozen seasons from 1979 to 2008: Implications for regional vegetation growth. Remote Sens. Environ. 121: 472-487. doi:10.1016/j.rse.2012.02.014.

Knott, J.A., J.M. Desprez, C.M. Oswalt and S. Fei. 2019. Shifts in forest composition in the eastern United States. Forest Ecol. Manag. 433: 176-183. doi:10.1016/j.foreco.2018.10.061

Kohyama, T.S., T.I. Kohyama and D. Sheil. 2019. Estimating net biomass production and loss from repeated measurements of trees in forests and woodlands: Formulae, biases and recommendations. Forest Ecol. Manag. 433: 729-740. doi:10.1016/j.foreco.2018.11.010. Kubiske, M.E., C.W. Woodall and C.C. Kern. 2019. Increasing atmospheric $\mathrm{CO}_{2}$ concentration stand development in trembling aspen forests: Are outdated density management guidelines in need of revision for all species? J. For. 117(1): 38-45. doi:10.1093/jofore/ fvy058.

LaDeau, S.L. and J.S. Clark. 2001. Rising $\mathrm{CO}_{2}$ levels and the fecundity of forest trees. Sci. 292(5514): 95-98. doi:10.1126/science. 1057547.

Lieffers, V.J., D. Sidders, T. Keddy, K.A. Solarik and P. Blenis. 2018. A partial deciduous canopy, coupled with site preparation, produces excellent growth of planted white spruce. Can. J. For. Res. 49(3): 270-280. doi:10.1139/cjfr-2018-0310.

Loehle, C. 1988. Tree life history strategies: The role of defenses. Can. J. For. Res. 18(2): 209-222. doi:10.1139/x88-032.

Loehle, C. 1995. Anomalous responses of plants to $\mathrm{CO}_{2}$ enrichment. OIKOS 73: 181-187. doi:10.2307/3545906.

Loehle, C. 2018. Model-based forecasts of North American forest growth: A review. Amer. J. Clim. Change 7(4): 519-547. doi:10.4236/ajcc.2018.74032.

Loehle, C. 2020. Historical forest changes in the western United States. Forest. Chron. 96(1): 36-49. 
Loehle, C. and K. Solarik. 2019. Forest growth changes in Canada. For. Chron. 95(3): 183-195. doi:10.5558/tfc2019-027.

Marchand, W., M.P. Girardin, S. Gauthier, H. Hartmann, O. Bouriaud, F. Babst and Y. Bergeron. 2018. Untangling methodological and scale considerations in growth and productivity trend estimates of Canada's forests. Environ. Res. Lett. 13(9): 093001. doi:10.1088/1748-9326/aad82a.

Mathias, J.M. and R.B. Thomas. 2018. Disentangling the effects of acidic air pollution, atmospheric $\mathrm{CO}_{2}$, and climate change on recent growth of red spruce trees in the Central Appalachian Mountains. Glob. Change Biol. 24(9): 3938-3953. doi:10.1111/gcb.14273.

McDowell, N.G. and C.D. Allen. 2015. Darcy's law predicts widespread forest mortality under climate warming. Nat. Clim. Change 5(7): 669-672. doi:10.1038/nclimate2641.

McDowell, N.G., A.P. Williams, C. Xu, W.T. Pockman, L.T. Dickman, S. Sevanto, R. Pangle, J. Limousin, J. Plaut, et al. 2016. Multi-scale predictions of massive conifer mortality due to chronic temperature rise. Nat. Clim. Change 6(3): 295-300. doi:10.1038/ nclimate2873.

McKenney, D., J. Pedlar and G. O'Neill. 2009. Climate change and forest seed zones: Past trends, future prospects and challenges to ponder. For. Chron. 85(2): 259-266. doi:10.5558/tfc85258-2.

McMahon, S.M., G.G. Parker and D.R. Miller. 2010. Evidence for a recent increase in forest growth. Proc. Nat. Acad. Sci. 107(8): 3611-3615. doi:10.1073/pnas.0912376107.

Motew, M.M. and C.J. Kucharik. 2013. Climate-induced changes in biome distribution, NPP, and hydrology in the upper Midwest U.S.: A case study for potential vegetation. J. Geophys. Res. 118(1): 248-264. doi:10.1002/jgrg.20025.

Nehrbass-Ahles, C., F. Babst, S. Klesse, M. Nötzli, O. Bouridaud, R. Neukom, M. Dobbertin and D. Frank. 2014. The influence of sampling design on tree-ring-based quantification of forest growth. Glob. Change Biol. 20(9): 2867-2885. doi:10.1111/gcb.12599.

Nowacki, G.J. and M.D. Abrams. 2015. Is climate an important driver of post-European vegetation change in the eastern United States? Glob. Change Biol. 21(1): 314-334. doi:10.1111/gcb.12663.

O'Sullivan, M., D.V. Spracklen, S.A. Batterman, S.R. Arnold, M. Gloor and W. Buermann. 2019. Have synergies between nitrogen deposition and atmospheric $\mathrm{CO}_{2}$ driven the recent enhancement of the terrestrial carbon sink? Glob. Biogeochem. Cycles 33(2): 163 180. doi:10.1029/2018gb005922.

Pan, Y., R. Birdsey, J. Hom and K. McCullough. 2009. Separating effects of changes in atmospheric composition, climate and land-use on carbon sequestration of U.S. Mid-Atlantic temperate forests. Forest Ecol. Manag. 259(2): 151-164. doi:10.1016/j.foreco.2009.09.049.

Peñuelas, J., J. Sardans, M. Estiarte, R. Ogaya, J. Carnicer, M. Coll, A. Barbeta, A. Rivas-Ubach, J. Lusià, et al. 2013. Evidence of current impact of climate change on life: A walk from genes to the biosphere. Glob. Change Biol. 19(8): 2303-2338. doi:10.1111/gcb.12143.
Pontius, J., J.M. Halman and P.G. Schaberg. 2016. Seventy years of forest growth and community dynamics in an undisturbed northern hardwood forest. Can. J. For. Res. 46(7): 959-967. doi:10.1139/ cjfr-2015-0304.

Pugh, T.A.M., M. Lindeskog, B. Smith, B. Poulter, A. Arneth, V. Haverd and L. Calle. 2019. Role of forest regrowth in global carbon sink dynamics. Proc. Nat. Acad. Sci. 116(10): 4382-4387. doi:10.1073/pnas.1810512116.

Rollinson, C.R., Y. Liu, A. Raiho, D.J.P. Moore, J. McLachlan, D.A. Bishop, A. Dye, J.H. Matthew, A. Hessl, et al. 2017. Emergent climate and $\mathrm{CO}_{2}$ sensitivities of net primary productivity in ecosystem models do not agree with empirical data in temperate forests of eastern North America. Glob. Change Biol. 23(7): 27552767. doi:10.1111/gcb.13626.

Searle, E.B. and H.Y.H. Chen. 2017. Tree size thresholds produced biased estimates of forest biomass dynamics. Forest Ecol. Manag. 400: 468-474. doi:10.1016/j.foreco.2017.06.042.

Talbot, J., S.L. Lewis, G. Lopez-Gonzalez, R.J.W. Brienen, A. Monteagudo, T.R. Baker, T.R. Feldpausch, Y. Malhi, M. Vanerwwel, et al. 2014. Methods to estimate aboveground wood productivity from long-term forest inventory plots. Forest Ecol. Manag. 320: 30-38. doi:10.1016/j.foreco.2014.02.021.

Thomas, R.Q., C.D. Canham, K.C. Weathers and C.L. Goodale. 2009. Increased tree carbon storage in response to nitrogen deposition in the US. Nat. Geosci. 3(1): 13-17. doi:10.1038/NGE0721.

Tian, H., G. Chen, M. Liu, C. Zhang, G. Sun, C. Lu, X. Xu, W. Ren, S. Pan, et al. 2010. Model estimates of net primary productivity, evapotranspiration, and water use efficiency in the terrestrial ecosystems of the southern United Sates during 1895-2007. Forest Ecol. Manag. 259(7): 1311-1327. doi:10.1016/j.foreco.2009.10.009.

Tian, H., G. Chen, C. Zhang, M. Liu, G. Sun, A. Chappelka, W. Ren, X. Xu, C. Lu, et al. 2012. Century-scale responses of ecosystem carbon storage and flux to multiple environmental changes in the southern United States. Ecosystems 15(4): 674-694. doi:10.1007/ s10021-012-9539-x.

Twine, T.E. and C.J. Kucharik. 2009. Climate impacts on net primary productivity trends in natural and managed ecosystems of the central and eastern United States. Agric. For. Meteorol. 149(12): 2143-2161. doi:10.1016/j.agrformet.2009.05.012.

Voelker, S.L., R.-M. Muzika, R.P. Guyette and M.C. Stambaugh. 2006. Historical $\mathrm{CO}_{2}$ growth enhancement declines with age in Quercus and Pinus. Ecol. Monogr. 76(4): 549-564. doi:10.1890/ 0012-9615(2006)076[0549:HCGEDW]2.0.CO,2.

von Storch, H., E. Zorita, J.M. Jones, Y. Dimitriev, F. GonzálezRouco and S.F.B. Tett. 2004. Reconstructing past climate from noisy data. Sci. 306(5696): 679-682. doi:10.1126/science.1096109.

West, D.C., T.W. Doyle, M.L. Tharp, J.J. Beauchamp, W.J. Platt and D.J. Downing. 1993. Recent growth increases in old-growth longleaf pine. Can. J. For. Res. 23(5): 846-853. doi:10.1139/x93-110. 